\title{
Genetic diversity of Pongamia pinnata in Bali, Indonesia using Inter Simple Sequence Repeat markers
}

\author{
NI LUH ARPIWI", I GUSTI AYU SUGI WAHYUNI, I KETUT MUKSIN \\ Department of Biology, Faculty of Mathematics and Natural Sciences, Universitas Udayana. Jl. Raya Kampus Unud No. 9, Jimbaran, Badung 80361, \\ Bali, Indonesia. Tel.: +62-361-701954, `email: arpiwi@unud.ac.id
}

Manuscript received: 10 June 2019. Revision accepted: 12 July 2019.

\begin{abstract}
Arpiwi NL, Wahyuni IGAS, Muksin IK. 2019. Genetic diversity of Pongamia pinnata in Bali, Indonesia using Inter Simple Sequence Repeat markers. Biodiversitas 20: 2134-2142. Pongamia pinnata (L.) Pierre is a member of family Leguminosae that produces seed oil for biodiesel feedstock. The aim of the present study was to determine genetic diversity of pongamia trees that grow in Bali using Inter Simple Sequence Repeat (ISSR) markers. This study is important to support the breeding program for the improvement of the biodiesel producing species. Leaf samples were taken from 26 pongamia trees grown on northern and southern coastal areas of Bali. Genomic DNA was isolated from fresh leaves sample and was amplified by Polymerase Chain Reaction (PCR) using 9 ISSR primers. The banding patterns of DNA after PCR were scored and tabulated into a binary matrix. Genetic distance was generated by pairwise distance using composite maximum likelihood. A dendrogram was constructed using Unweighted Pair Group Method Arithmetic (UPGMA) method. The binary matrix was further analyzed for Nonmetric Multidimensional Scaling (NMDS) with Primer E V.6 software. DNA concentrations ranged from $98.59-100.55 \mathrm{ng} / \mu \mathrm{L}$ with sufficient quality for PCR. The number of alleles for 9 primers was 43 , the number of the polymorphic band was 35 , and the number of monomorphic bands was 8 . Percentage of polymorphism ranged from 50 to $100 \%$. Cluster analysis of 26 DNA of pongamia trees showed that the trees were grouped into two, namely group I and II. Group I consisted of two trees only, namely Uma Anyar 1 and Penarukan 1. Group II consisted of 24 pongamia trees which were divided into 3 subgroups, namely IIA, IIB, and IIC with close genetic distance. Analysis of NMDS supported cluster analysis that 23 out of 26 pongamia trees had close genetic distance, and possibly they come from a similar source. Genetic diversity of pongamia in Bali needs to be widen possibly by the introduction of new planting materials from across Indonesia or seed procurement from different sources.
\end{abstract}

Keywords: Bali, genetic diversity, ISSR, Pongamia pinnata

\section{INTRODUCTION}

Pongamia pinnata (L.) Piere known as pongamia is a plant belonging to the family Leguminosae that has the potential to be used as a raw material for biodiesel and generally grows on the coast naturally (Arpiwi et al. 2013a). Pongamia cultivation is very important to support the diversification of renewable energy sources, especially biodiesel. One step of development is the selection of pongamia trees to get the best phenotype, which is known as plus tree that can be used as parent trees in vegetative propagation (Kesari et al. 2008). The conventional selection method, however, is greatly influenced by environmental factors and molecular data such the existence of genetic diversity is important to support breeding for the improvement of the species (Sharma et al. 2011).

Pongamia is a perennial plant able to grow on critical lands such as infertile and saline soils so that the cultivation of this plant will not compete with fertile agricultural land and will not interfere with the productivity of agricultural crops (Moser 2009). In the infertile soil, pongamia is able to absorb free nitrogen from the air through symbiosis with nitrogen-fixing bacteria called Rhizobia (Arpiwi et al 2013b). This nitrogen-free fixing ability reduces the need for additional $\mathrm{N}$ fertilizer in the growth and development of these plants, thereby saving costs. Pongamia also able to grow on saline soils up to $200 \mathrm{mM} \mathrm{NaCl}$ and tolerance to waterlogging with freshwater (Arpiwi et al. 2013a) which make the species survive in coastal areas, riverbanks, and estuaries. Ecologically, pongamia is capable of living on almost all types of soil including sandy soil, rocky soil, and clay so that it makes it easier to use these critical lands. Its distribution starts from the coast up to an altitude of 1200 meters above sea level, annual rainfall of 500-2500 mm, temperatures above $0^{\circ} \mathrm{C}$ to $38^{\circ} \mathrm{C}$

Selection of pongamia tree aims to find trees with superior morphological characteristics and with high oil content. In Bali, most of pongamia trees grow on the beach with scatter distribution and very rarely grow in a big group. The only pongamia population found in Bali is in Lovina Beach, Buleleng District, Bali Province, Indonesia. The population is composed at least by 30 mature pongamia trees with oil content ranging from $28-31 \%$ (Arpiwi et al. 2017). The number of pongamia trees in Bali is 126 , and most of them are found in the northern coastal part of the island in Buleleng District. Some pongamia trees are found in the South part of the island in a small number. Among those 126 trees, eight trees having superior morphological characteristics are identified as plus trees (Arpiwi et al. 2018).

Information on genetic diversity of pongamia in Bali is 
not available. Genetic diversity is the diversity at the level of genes or DNA of a species or population. High genetic diversity will ensure the survival of a species or population because of its wide adaptability (Martín et al. 2012). One method to determine the genetic diversity of plant species is to use molecular markers such as Inter-Simple Sequence Repeat (ISSR). ISSR markers have been widely used for genetic diversity studies of plant species, such as jatropha (Grativol et al. 2011), apricot (Kumar et al. 2009) and pongamia (Sahoo et al. 2010). The advantage of this marker is producing many DNA fragments in a single reaction where each fragment is called a locus, fast, simple and inexpensive ( $\mathrm{Ng}$ and Tan 2015). Based on the advantages mentioned above, the ISSR markers were chosen to analyze the genetic diversity of Pongamia pinnata that grows along the coast of Bali Island.

In Java Island, Indonesia, genetic diversity of pongamia's population is studied using RAPD markers. Among 5 populations studied, 4 populations have a close genetic relationship, and only one population from Baluran has high genetic diversity, and Baluran probably the center of genetic diversity of pongamia in Java Island (Aminah et al. 2017). In India, genetic diversity of pongamia is assessed using Amplified Fragment Length Polymorphism (AFLP) and Three Endonuclease (TE) AFLP where samples are taken from diverse locations in Delhi. It is found that high genetic diversity of pongamia due to wide ranges of sample locations (Sharma et al. 2011). Another study about inter and intra population genetic diversity of pongamia in Orrisa, India using ISSR markers concludes an immediate need to widen the base of genetic diversity of the species (Sahoo et al. 2010). Genetic diversity of pongamia in Bali has never been investigated. Therefore, it is very urgently needed for the conservation strategy and breeding program of the species.

\section{MATERIALS AND METHODS}

\section{Leaf sample collection}

Fully expanding leaf samples were taken from pongamia trees that grow in several villages in Bali (Figure 1) based on the previous research about conservation and selection of plus trees of Pongamia pinnata by Arpiwi et al. (2018). In Buleleng, District leaf samples were taken from Penarukan, Pemaron, Kalibukbuk, Temukus, Uma Anyar, Kalisada, Celukan Bawang, Pengulon, and Sumber Klampok. Samples from Denpasar (Pemogan Village, Serangan Village, and Sanur) and Badung District including Tanjung Benoa Village. Total sampling sites were 13 villages and the data about site of sampling locations and GPS coordinates is presented in table 1. Each village was sampled with two trees to give a total of 26 samples. Leaf samples wrapped in aluminum foil, labeled, put in a plastic bag, then stored in a box containing silica gel and then transported to the laboratory.

\section{DNA isolation and quantification}

DNA was isolated from the leaves using the DNeasy Plant Mini Kit (Qiagen) according to the protocol suggested by the manufacturer. Fresh leaves samples (100 mg) were crushed using mortar and pestle, which added liquid nitrogen to form fine powder. The powder was put into $1.5 \mathrm{~mL}$ Eppendorf tube then added with $400 \mu \mathrm{L}$ buffer AP1 and $4 \mu \mathrm{L}$ RNase A. The tube was vortexed to mix the buffer and the sample evenly. The mixture was incubated at $65^{\circ} \mathrm{C}$ for 10 minutes, while turning it back and forth three times during incubation. Buffer AP2 $(130 \mu \mathrm{L})$ was added then incubated in ice for 5 minutes and centrifuged at a speed of 14,000 rpm for 5 minutes. The lysate was poured into QIAshredder Mini Spin Column using a micropipette then centrifuged for 2 minutes at $14,000 \mathrm{rpm}$ to form pellet deposit at the bottom of the column. The upper liquid was transferred to a new tube without touching the pellet. Buffer AP3 (1.5 volume) was added to the column then mix using a pipette. The liquid was transferred to DNeasy Mini Spin Column and then place this column in a new 2 $\mu \mathrm{L}$ tube. Buffer AW $(500 \mu \mathrm{L})$ was added, then centrifuged for 1 minute $8000 \mathrm{rpm}$. The liquid was discarded then Dneasy Mini Spin Column was transferred into1.5 mL Eppendorf tube. Warm buffer AE $(100 \mu \mathrm{L})$ was added to DNeasy membrane, incubated for 5 minutes at room temperature, then centrifuged for one minute at $8000 \mathrm{rpm}$. The DNA was collected in $1.5 \mathrm{~mL}$ Eppendorf tube and then visualized in $1 \%$ agarose gel at 120 volts for 40 minutes. As a size marker, $1 \mathrm{~Kb}$ DNA ladder (Axygen) was run in the gel and DNA quality was measured with a Nanodrop spectrophotometer.

Table 1. Site of sampling locations (village, district, regency) and GPS coordinates

\begin{tabular}{cllllcc}
\hline No & \multicolumn{1}{c}{ Village } & \multicolumn{1}{c}{ Distric } & Regency & Longitude & Latitude & Elevation \\
\hline 1 & Penarukan & Buleleng & Buleleng & $08^{\circ} 04^{\prime} 58.4^{\prime \prime}$ & $115^{\circ} 06^{\prime} 55.9^{\prime \prime}$ & 9 \\
2 & Pemaron & Buleleng & Buleleng & $08^{\circ} 07^{\prime} 30.3^{\prime \prime}$ & $115^{\circ} 03^{\prime} 46.7^{\prime \prime}$ & 20 \\
3 & Kalibukbuk & Buleleng & Buleleng & $08^{\circ} 09^{\prime} 30.5^{\prime \prime}$ & $115^{\circ} 011^{\prime} 33.2^{\prime \prime}$ & 9 \\
4 & Temukus & Banjar & Buleleng & $08^{\circ} 10^{\prime} 55.2^{\prime \prime}$ & $114^{\circ} 58^{\prime} 40.0^{\prime \prime}$ & 11 \\
5 & Uma Anyar & Seririt & Buleleng & $08^{\circ} 11^{\prime} 03.3^{\prime \prime}$ & $114^{\circ} 54^{\prime} 52.4^{\prime \prime}$ & 13 \\
6 & Kalisada & Seririt & Buleleng & $08^{\circ} 11^{\prime} 27.6^{\prime \prime}$ & $114^{\circ} 53^{\prime} 11.8^{\prime \prime}$ & 14 \\
7 & Celukan Bawang & Gerokgak & Buleleng & $08^{\circ} 11^{\prime} 41.0^{\prime \prime}$ & $114^{\circ} 50^{\prime} 01.7^{\prime \prime}$ & 13 \\
8 & Pengulon & Gerokgak & Buleleng & $08^{\circ} 11^{\prime} 32.0^{\prime \prime}$ & $114^{\circ} 49^{\prime} 22.2^{\prime \prime}$ & 42 \\
9 & Sumber Kelampok & Gerokgak & Buleleng & $08^{\circ} 08^{\prime} 36.5^{\prime \prime}$ & $114^{\circ} 32^{\prime} 20.5^{\prime \prime}$ & 14 \\
10 & Serangan & Denpasar Selatan & Denpasar & $08^{\circ} 43^{\prime} 35.7^{\prime \prime}$ & $115^{\circ} 13^{\prime} 49.0^{\prime \prime}$ & 16 \\
11 & Pemogan & Denpasar Selatan & Denpasar & $08^{\circ} 43^{\prime} 34.6^{\prime \prime}$ & $115^{\circ} 111^{\prime} 35.4^{\prime \prime}$ & 13 \\
12 & Sanur & Denpasar Selatan & Denpasar & $08^{\circ} 41^{\prime} 35.7^{\prime \prime}$ & $115^{\circ} 15^{\prime} 59.7^{\prime \prime}$ & 17 \\
13 & Tanjung Benoa & Kuta Selatan & Badung & $08^{\circ} 45^{\prime} 13.2^{\prime \prime}$ & $115^{\circ} 13^{\prime} 16.5^{\prime \prime}$ & 13 \\
\hline
\end{tabular}




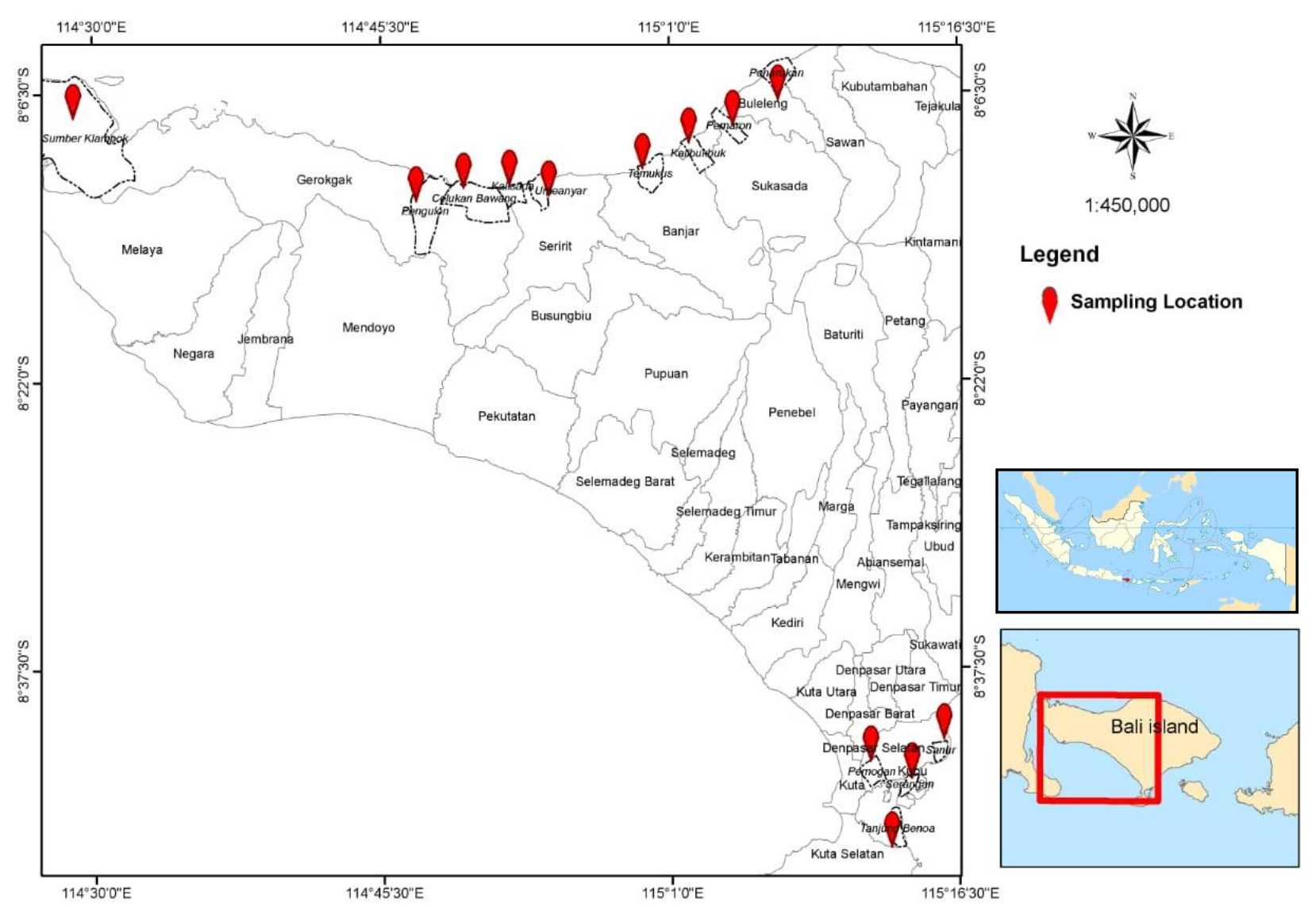

Figure 1. Sites of sampling locations of Pongamia pinnata leaves in Bali, Indonesia including 13 villages, namely Penarukan, Pemaron, Kalibukbuk, Temukus, Uma Anyar, Kalisada, Celukan Bawang, Pengulon, Sumber Klampok, Tanjung Benoa, Pemogan, Serangan and Sanur

Tabel 2. ISSR primers with annealing temperatures

\begin{tabular}{lcc}
\hline Primer & Primer sequnce 5' $\mathbf{3}^{\mathbf{1}}$ & T annealing $\left({ }^{\mathbf{0}} \mathbf{C}\right)$ \\
\hline UBC 807 & (AG)8GT & 52 \\
UBC 808 & (AG)8C & 52 \\
UBC 810 & (GA)8T & 54 \\
UBC 812 & (GA)8A & 52 \\
UBC 818 & (CA)8G & 54 \\
UBC 820 & (GT)8T & 52 \\
UBC 823 & (TC)8C & 52 \\
UBC 825 & (AC)8T & 52 \\
UBC 826 & (AC)8C & 54 \\
\hline
\end{tabular}

\section{Polymerase Chain Reaction (PCR)}

DNA was amplified by Polymerase Chain Reaction (PCR) using ISSR primers (Table 2) based on other researches (Kesari et al. 2010 and Sahoo et al. 2010) The total volume of the mixture for PCR reaction was $20 \mathrm{uL}$ containing $10 \mu \mathrm{L}$ HotStarTaq Plus Master Mix, $0.5 \mu \mathrm{L}$ primer, $2 \mu \mathrm{L}$ DNA template and RNase-Free water is added to a final volume of $20 \mathrm{uL}$. PCR machine was programmed as follows. Initial activation for 5 minutes at $95^{\circ} \mathrm{C}$, denaturation for 0.5 minutes at $94^{\circ} \mathrm{C}$, annealing for 0.5 minutes at primer's annealing temperature, extension for 1 minute at $72^{\circ} \mathrm{C}$ and the last extension for 10 minutes at $72^{\circ} \mathrm{C}$. The PCR product was separated using $1.5 \%$ agarose gel with $1 \mathrm{X}$ TAE buffer, stained with ethidium bromide and a 100 bp ladder DNA marker (Axygen) was included the gel. Electrophoresis was carried out for 40 minutes at 100 volts. The gel was placed on the UV transilluminator to see DNA banding patterns and then photographed with a digital camera.

\section{Data analysis}

DNA bands after PCR were analyzed by counting the number of bands for each primer, the number of alleles, the number of polymorphic bands (bands that were not amplified in all samples), the number of monomorphic bands (bands that amplified in all samples) and percentage of polymorphism. DNA bands were scored and tabulated into a binary matrix, where the present band was scored A, and the absent band scored T. The matrix was aligned and analyzed using MEGA X software. Genetic distance was generated by pairwise distance using composite maximum likelihood. A dendrogram was constructed using Unweighted Pair Group Method Arithmetic (UPGMA) method with 1000 bootstrap replications. The binary matrix of absent and present of DNA bands were further analyzed for Nonmetric Multidimensional Scaling (NMDS) with Primer E V.6 software using Euclidean distance. 


\section{RESULTS AND DISCUSSION}

\section{DNA quantity and quality}

DNA concentrations ranged from $98.59-100.55 \mathrm{ng} / \mu \mathrm{L}$. The quality of DNA was indicated by A260/A280 ratio that ranges from 1.77 to 1.91 , and A260/A230 ratio ranged from 1.1 to 7.8 (Table 3). According to Weiss et al. (2007) pure DNA has a ratio of A260/A280 range from 1.88 to 2.2 and the ratio of A260/A230 range from 1.5 to 1.8. In this research, the ratio A260/A280 was within the range of pure DNA. However, ratios A260/A230 were mostly higher than the normal range for pure DNA. One DNA sample (Pemogan 2) had a lower ratio A260/A230 of 1.1 . According to Demeke and Jenkins (2010), the ratio of A260/A230 less than 2 indicates contamination of carbohydrate, salt, and organic solvent in the DNA sample. In the present study, although most DNA samples had a higher ratio of A260/A230, the DNA concentrations were high (98.59-100.55 $\mathrm{ng} / \mu \mathrm{L})$, which indicated good DNA quantity. Ramirez et al. (2018) got lower DNA concentration from Theobroma cacao leaves, which is 3.33-37.53 ng/ $\mu$ using different DNA kit from the present study.

\section{Profile of genomic DNA}

In general, pongamia genomic DNA profiles showed bright bands with size higher than 10.000 bp (Figure 2). There were 4 DNA having smear bands (samples number 1, 2, 4, and 10), and there was one sample with a blurry band (sample number 3). Smears indicate DNA degradation (Stagnati et al. 2017). Although there was genomic DNA degradation in 4 samples, the quality of
DNA was still good as evidenced by the 260/280 ratio of the samples whose smears ranged from 1.87 to 1.95 .

\section{Analysis of polymorphism}

Amplification of 26 DNA samples with nine ISSR primers produced DNA banding pattern with the number of alleles, the number of polymorphic and monomorphic bands and percentage of polymorphism (Table 4). The number of alleles for nine primers was 43 , the number of the polymorphic band was 35, and the number of monomorphic bands was 8 . Percentage of polymorphism ranged from 50 to $100 \%$. Among the 9 ISSR primers, UBC 810 produced the highest number of alleles (12) and the number of polymorphic bands (11) with $92 \%$ of polymorphism (Figure 3). The efficiency of molecular markers can be measured by the percentage of polymorphism (Grativol et al. 2011). Primer UBC 825 produced $100 \%$ polymorphism and primers UBC 807,810 and 826 produced $\geq 80 \%$ polymorphism. These markers were efficient in determining the genetic diversity of pongamia. A similar study about the genetic diversity of $P$. pinnata in India by Sahoo et al. (2010) found a lower percentage of polymorphism (range from 37.50 to $82.35 \%$ ) using 10 ISSR primers.

\section{Genetic distance}

The genetic distance of pongamia trees based on the ISSR markers ranged from 0.000 to 1.324 (Table 5). Sample Serangan 2 and Celukan Bawang 1 had 0.000 genetic distance suggesting they were identical, while sample Uma Anyar 1 and Tanjung Benoa 2 had 1.324 genetic distance suggesting divergent.

Table 3. Quality and quality of genomic DNA of Pongamia pinnata

\begin{tabular}{|c|c|c|c|c|c|c|}
\hline No & Sample & DNA concentration $(\mathrm{ng} / \mu \mathrm{L})$ & $\mathbf{A 2 6 0}$ & $\mathbf{A 2 8 0}$ & $260 / 280$ & $260 / 230$ \\
\hline 1 & Penarukan 1 & 66.44 & 1.329 & 0.696 & 1.910 & 2.840 \\
\hline 2 & Penarukan 2 & 87.79 & 1.756 & 0.930 & 1.89 & 2.10 \\
\hline 3 & Pemaron 1 & 97.3 & 1.946 & 1.042 & 1.87 & 1.96 \\
\hline 4 & Pemaron 2 & 69.47 & 1.389 & 0.735 & 1.89 & 5.11 \\
\hline 5 & Kalibukbuk 1 & 46.78 & 0.936 & 0.482 & 1.94 & 5.77 \\
\hline 6 & Kalibukbuk2 & 108.82 & 2.176 & 1.128 & 1.93 & 2.65 \\
\hline 7 & Temukus 1 & 87.81 & 1.756 & 0.897 & 1.96 & 3.48 \\
\hline 8 & Temukus 2 & 119.81 & 2.396 & 1.266 & 1.89 & 2.54 \\
\hline 9 & Uma Anyar 1 & 61.67 & 1.233 & 0.621 & 1.98 & 7.58 \\
\hline 10 & Uma Anyar 2 & 63.39 & 1.268 & 0.652 & 1.94 & 4.98 \\
\hline 11 & Kalisada 1 & 100.98 & 2.02 & 1.087 & 1.86 & 2.04 \\
\hline 12 & Kalisada 2 & 67.6 & 1.352 & 0.689 & 1.96 & 3.90 \\
\hline 13 & Celukan Bawang 1 & 72.43 & 1.449 & 0.747 & 1.94 & 4.52 \\
\hline 14 & Celukan Bawang 2 & 77.24 & 1.545 & 0.826 & 1.87 & 2.17 \\
\hline 15 & Pengulon 1 & 63.96 & 1.279 & 0.652 & 1.96 & 6.47 \\
\hline 16 & Pengulon 2 & 113.41 & 2.268 & 1.244 & 1.82 & 1.97 \\
\hline 17 & Sumber Klampok 1 & 125.73 & 2.515 & 1.344 & 1.87 & 2.08 \\
\hline 18 & Sumber Klampok 2 & 98.59 & 1.972 & 1.087 & 1.81 & 1.84 \\
\hline 19 & Tanjung Benoa 1 & 72.2 & 1.444 & 0.801 & 1.800 & 2.24 \\
\hline 20 & Tanjung Benoa 2 & 158.75 & 3.175 & 1.713 & 1.85 & 2.14 \\
\hline 21 & Pemogan 1 & 129.58 & 2.592 & 1.54 & 1.68 & 1.45 \\
\hline 22 & Pemogan 2 & 67.85 & 1.357 & 0.814 & 1.67 & 1.10 \\
\hline 23 & Serangan 1 & 87.79 & 1.756 & 0.958 & 1.83 & 2.23 \\
\hline 24 & Serangan 2 & 100.55 & 2.011 & 1.103 & 1.82 & 2.03 \\
\hline 25 & Sanur 1 & 56.82 & 1.136 & 0.607 & 1.87 & 4.19 \\
\hline 26 & Sanur 2 & 79.02 & 1.58 & 0.894 & 1.77 & 3.79 \\
\hline
\end{tabular}



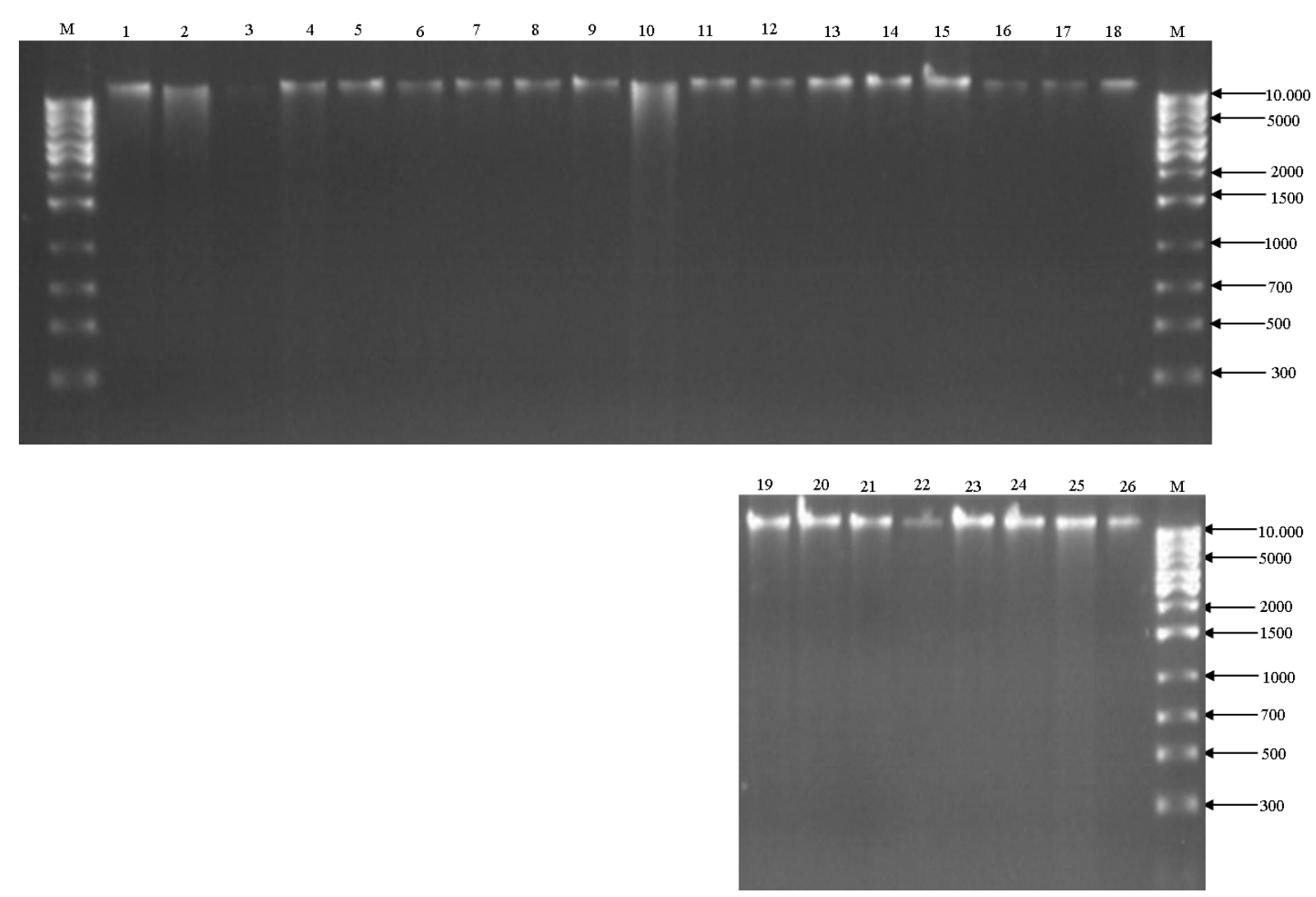

Figure 2. Profile of genomic DNA of 26 Pongamia pinnata leaf samples, $M=1 \mathrm{~Kb}$ ladder DNA marker, Number 1-26 were samples taken from each village, namely $1=$ Penarukan $1,2=$ Penarukan $2,3=$ Pemaron $1,4=$ Pemaron 2, $5=$ Kalibukbuk $1,6=$ Kalibukbuk 2 , $7=$ Temukus 1, $8=$ Temukus 2, $9=$ Uma Anyar 1, $10=$ Uma Anyar 2, 11= Kalisada 1, $12=$ Kalisada 2, 13= Celukan Bawang 1, $14=$ Celukan Bawang 2, $15=$ Pengulon 1, $16=$ Pengulon 2, $17=$ Sumber Klampok 1, $18=$ Sumber Klampok 2, $19=$ Tanjung Benoa 1, $20=$ Tanjung Benoa 2, 21 = Pemogan 1, $22=$ Pemogan 2, $23=$ Serangan 1, $24=$ Serangan 2, $25=$ Sanur 1, $26=$ Sanur 2.

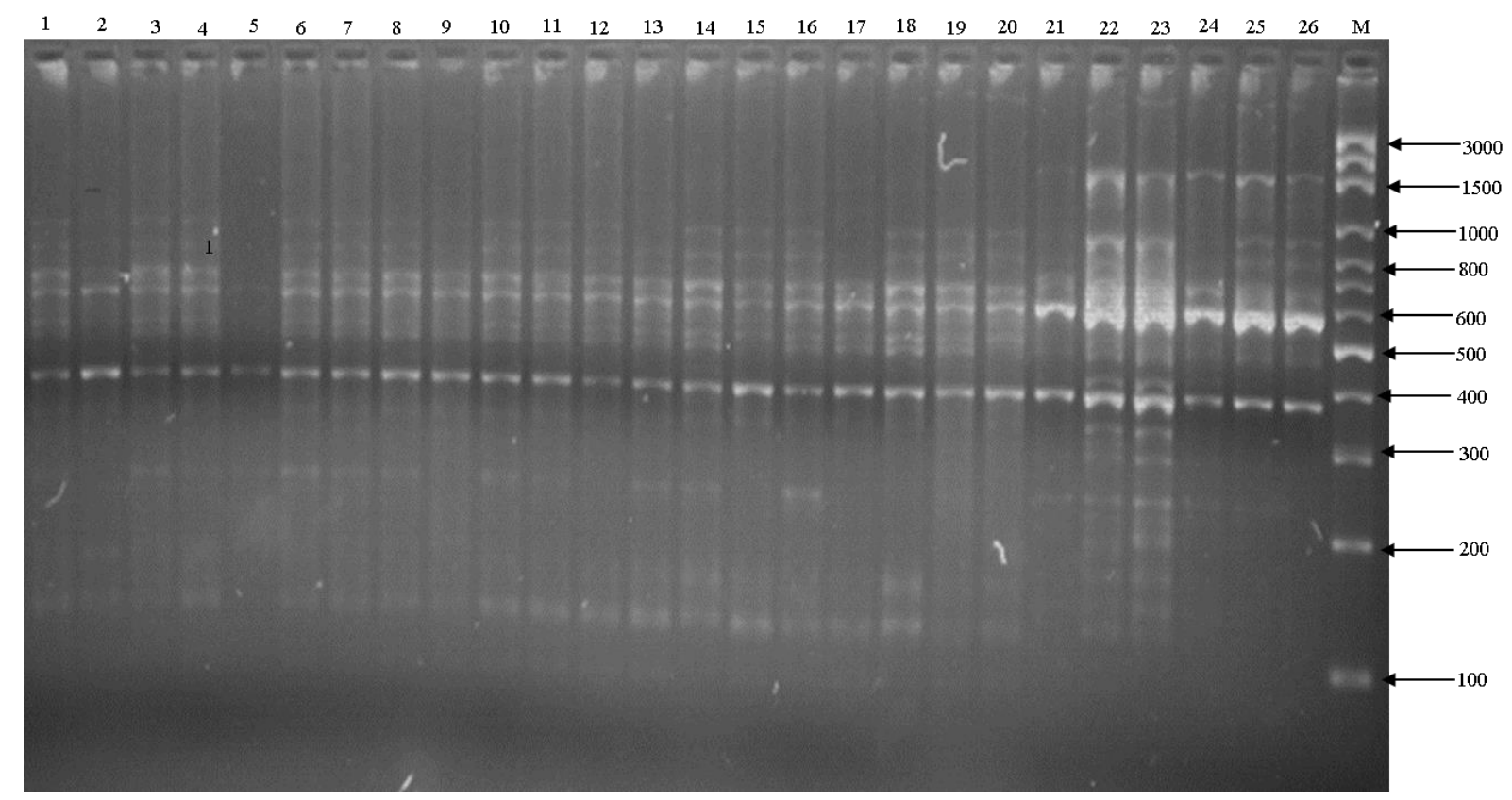


Figure 3. DNA amplification product using primer UBC 810. $\mathrm{M}=1 \mathrm{~Kb}$ ladder DNA marker, Number 1-26 were samples taken from each village, namely $1=$ Penarukan $1,2=$ Penarukan $2,3=$ Pemaron $1,4=$ Pemaron $2,5=$ Kalibukbuk $1,6=$ Kalibukbuk $2,7=$ Temukus 1, $8=$ Temukus 2, $9=$ Uma Anyar 1, $10=$ Uma Anyar 2, 11= Kalisada 1, $12=$ Kalisada 2, $13=$ Celukan Bawang $1,14=$ Celukan Bawang 2, $15=$ Pengulon 1, $16=$ Pengulon 2, $17=$ Sumber Klampok 1, $18=$ Sumber Klampok 2, $19=$ Tanjung Benoa $1,20=$ Tanjung Benoa 2, 21 = Pemogan 1, $22=$ Pemogan 2, $23=$ Serangan 1, $24=$ Serangan 2, $25=$ Sanur 1, $26=$ Sanur 2.

Table 4. Polymorphism of 26 DNA samples of Pongamia pinnata using 9 ISSR primers

\begin{tabular}{lccccc}
\hline Primer & Band size (bp) & No of alleles & Polymorphic bands & Monomorphic bands & $\begin{array}{c}\text { Percentage of } \\
\text { polymorphism }\end{array}$ \\
\hline UBC 807 & $190-2000$ & 5 & 4 & 1 & 80 \\
UBC 808 & $240-290$ & 2 & 1 & 1 & 50 \\
UBC 810 & $300-850$ & 12 & 11 & 1 & 92 \\
UBC 812 & $300-1000$ & 4 & 3 & 1 & 75 \\
UBC 818 & $250-500$ & 3 & 2 & 1 & 67 \\
UBC 820 & $250-800$ & 3 & 2 & 1 & 67 \\
UBC 823 & $300-700$ & 4 & 3 & 0 & 75 \\
UBC 825 & $300-650$ & 3 & 3 & 1 & 80 \\
UBC 826 & $250-1500$ & 7 & 6 & 8 & \\
Total & & 43 & 35 & & 86 \\
\hline
\end{tabular}

\section{Cluster analysis}

Cluster analysis of 26 DNA of pongamia trees was presented in a dendrogram in Figure 4. It was shown that the trees were grouped into two, namely group I and II. Group I consisted of two trees only, namely Uma Anyar 1 and Penarukan 1. Group II consisted of 24 pongamia trees which were divided into 3 subgroups at the branch length of 0.20 , namely subgroup IIA, IIB, IIC. Subgroup IIA contained 8 trees, namely Temukus 2, Temukus 1 , Tanjung Benoa 2, Kalibukbuk 1, Pemaron 2, Penarukan 1, Pemaron 1, and Sumber Klampok 1. Subgroup IIB contained 15 pongamia trees, namely Tanjung Benoa 1, Pemogan 1, Sumber Klampok 2, Celukan Bawang 1, Pengulon 2, Pengulon1, Celukan Bawang 2, Kalisada 2, Kalisada 1, Uma Anyar 2, Serangan 2, Serangan 1, Pemogan 2, Sanur 2 , and Sanur 1. Sub group IIC contained one tree, namely Kalibukbuk 2. Subgroup IIC contained one pongamia tree, namely Kalibukbuk 2.

Cluster analysis of pongamia trees into the dendrogram (Figure 4) with genetic distance (Table 5) gave a clearer picture of their genetic diversity. As can be seen from figure 4 that some pongamia trees were grouped based on growing location with narrow genetic distance $(0.0027$ 0.165 ). For example: within subgroup IIA, Temukus 1 dan Temukus 2 were grouped with genetic distance 0.165. Within subgroup IIB, Kalisada 1 dan Kalisada 2 were grouped with genetic distance 0.027 , Serangan 1 and Serangan 2 with genetic distance 0.027, Sanur 1 and Sanur 2 with genetic distance 0.057 . Grouping of trees based on growing location with narrow genetic distance indicates that they have a very close relationship; possibly they come from the same source. There were some pongamia trees from different locations grouped together with small genetic distance. For examples, within subgroup IIA, Tanjung Benoa 2 and Kalibukbuk 1 were grouped with genetic distance 0.092, Penarukan 2 and Pemaron 1 were grouped with genetic distance 0.057 . Within subgroup IIB, Sumber Klampok 2 and Celukan Bawang 1 were grouped with genetic distance 0.057. Interestingly, Pengulon 1 and Celukan Bawang 2 grouped with 0.000 genetic distance indicating the trees were genetically similar although they grow at different locations. Trees from northern coast and southern coast of Bali Island were interspersed within subgroup IIA and IIB in figure 4 indicating they were genetically closely related. According to Aminah et al. (2017), closely related population of pongamia possibly because they come from a similar source.

Narrow genetic distance among pongamia trees in the present study possibly the trees come from similar seed source, where the mode of seed dispersal may able to explain this. As pongamia grow on beaches, they may drop pods to seawater or estuary, and pods travel along the coastal line while dispersing seeds. Under laboratory experiment, pongamia pod can float up to 3 months on saline water without losing seed viability. Seedlings are frequently found growing on beaches (Nakanishi 1988). In the present study, it is likely that pongamia that grows along northern and southern coast of the island comes from a similar seed source. Therefore the trees had very close genetic relatedness as indicated by small genetic distance. The presence of genetic divergent from view trees, namely Uma Anyar 1, Panarukan 1, Kalibukbuk 2, and Sumber Klampok possibly associated with the mating system of the species (Loveless 1992). Pongamia pinnata has an explosive pollen release mechanism that requires legitimate pollinators, and this contributes to cross-pollination (Raju and Rao 2006).

Research about the genetic diversity of 5 pongamia populations in Java island of Indonesia shows that the populations are clustered according to growing locations. Four populations, namely Carita, Batu Karas, Kebumen and Alas Purwo that grow in the south coast have a close genetic relationship while one population, namely Baluran in the north coast has separate from others indicating that Baluran population has the highest genetic diversity (Aminah et al. 2017). In Bali, most pongamia trees scatter or grow in small groups (Arpiwi et al. 2018). Therefore, the study of genetic diversity of pongamia in Bali based on individual tree growing in different locations. 
BIODIVERSITAS

Volume 20, Number 8, August 2019

Pages: 2134-2142
ISSN: 1412-033X

E-ISSN: 2085-4722

DOI: $10.13057 /$ biodiv/d200806 
Table 5. Genetic distance of 26 DNA of Pongamia pinnata based on variation in ISSR markers

\begin{tabular}{|c|c|c|c|c|c|c|c|c|c|c|c|c|c|c|c|c|c|c|c|c|c|c|c|c|c|c|}
\hline \multirow[b]{2}{*}{$\overline{1}$} & 1 & 2 & 3 & 4 & 5 & 6 & 7 & 8 & 9 & 10 & 11 & 12 & 13 & 14 & 15 & 16 & 17 & 18 & 19 & 20 & 21 & 22 & 23 & 24 & 25 & 26 \\
\hline & & & & & & & & & & & & & & & & & & & & & & & & & & \\
\hline 2 & 0.834 & & & & & & & & & & & & & & & & & & & & & & & & & \\
\hline 3 & 0.165 & 0.947 & & & & & & & & & & & & & & & & & & & & & & & & \\
\hline 4 & 0.273 & 1.324 & 0.273 & & & & & & & & & & & & & & & & & & & & & & & \\
\hline 5 & 0.324 & 0.827 & 0.398 & 0.338 & & & & & & & & & & & & & & & & & & & & & & \\
\hline 6 & 0.324 & 0.898 & 0.263 & 0.338 & 0.125 & & & & & & & & & & & & & & & & & & & & & \\
\hline 7 & 0.419 & 1.194 & 0.419 & 0.398 & 0.944 & 0.944 & & & & & & & & & & & & & & & & & & & & \\
\hline 8 & 0.211 & 0.898 & 0.398 & 0.419 & 0.211 & 0.211 & 0.673 & & & & & & & & & & & & & & & & & & & \\
\hline 9 & 0.165 & 0.995 & 0.492 & 0.338 & 0.263 & 0.263 & 0.523 & 0.027 & & & & & & & & & & & & & & & & & & \\
\hline 10 & 0.211 & 0.898 & 0.263 & 0.273 & 0.324 & 0.211 & 0.673 & 0.125 & 0.165 & & & & & & & & & & & & & & & & & \\
\hline 11 & 0.324 & 0.834 & 0.398 & 0.419 & 0.324 & 0.211 & 0.673 & 0.125 & 0.165 & 0.057 & & & & & & & & & & & & & & & & \\
\hline 12 & 0.324 & 0.827 & 0.398 & 0.338 & 0.211 & 0.057 & 0.944 & 0.211 & 0.165 & 0.324 & 0.324 & & & & & & & & & & & & & & & \\
\hline 13 & 0.263 & 1.161 & 0.324 & 0.419 & 0.165 & 0.165 & 0.673 & 0.263 & 0.211 & 0.398 & 0.398 & 0.090 & & & & & & & & & & & & & & \\
\hline 14 & 0.398 & 0.947 & 0.324 & 0.338 & 0.398 & 0.398 & 0.338 & 0.398 & 0.492 & 0.398 & 0.263 & 0.623 & 0.834 & & & & & & & & & & & & & \\
\hline 15 & 0.285 & 0.227 & 0.736 & 1.000 & 0.736 & 0.869 & 0.736 & 0.736 & 0.559 & 0.869 & 0.736 & 0.869 & 1.000 & 0.285 & & & & & & & & & & & & \\
\hline 16 & 0.211 & 0.898 & 0.398 & 0.171 & 0.125 & 0.211 & 0.419 & 0.125 & 0.165 & 0.211 & 0.211 & 0.324 & 0.398 & 0.263 & 0.442 & & & & & & & & & & & \\
\hline 17 & 0.492 & 0.827 & 0.398 & 0.338 & 0.125 & 0.211 & 0.944 & 0.492 & 0.623 & 0.492 & 0.324 & 0.324 & 0.263 & 0.263 & 0.736 & 0.211 & & & & & & & & & & \\
\hline 18 & 0.211 & 0.898 & 0.398 & 0.273 & 0.834 & 0.898 & 0.419 & 0.834 & 0.623 & 0.492 & 0.834 & 0.898 & 0.947 & 0.263 & 0.355 & 0.492 & 0.898 & & & & & & & & & \\
\hline 19 & 0.263 & 0.947 & 0.324 & 0.338 & 0.398 & 0.623 & 0.523 & 0.398 & 0.492 & 0.398 & 0.398 & 0.947 & 0.898 & 0.057 & 0.285 & 0.263 & 0.398 & 0.165 & & & & & & & & \\
\hline 20 & 0.211 & 0.827 & 0.263 & 0.338 & 0.211 & 0.211 & 0.944 & 0.492 & 0.398 & 0.324 & 0.492 & 0.211 & 0.090 & 0.947 & 0.736 & 0.492 & 0.324 & 0.834 & 0.947 & & & & & & & \\
\hline 21 & 0.263 & 0.995 & 0.324 & 0.419 & 0.165 & 0.165 & 0.673 & 0.398 & 0.324 & 0.398 & 0.398 & 0.165 & 0.057 & 0.834 & 0.559 & 0.398 & 0.263 & 0.947 & 0.898 & 0.027 & & & & & & \\
\hline 22 & 0.398 & 0.623 & 0.211 & 0.419 & 0.398 & 0.398 & 0.673 & 0.623 & 0.834 & 0.947 & 0.947 & 0.623 & 0.492 & 0.834 & 0.736 & 0.398 & 0.623 & 0.623 & 0.834 & 0.398 & 0.324 & & & & & \\
\hline 23 & 0.211 & 1.231 & 0.263 & 0.092 & 0.492 & 0.492 & 0.273 & 0.834 & 0.623 & 0.492 & 0.834 & 0.492 & 0.398 & 0.263 & 0.559 & 0.324 & 0.492 & 0.125 & 0.263 & 0.324 & 0.398 & 0.398 & & & & \\
\hline 24 & 0.263 & 1.161 & 0.324 & 0.419 & 0.165 & 0.165 & 0.673 & 0.263 & 0.211 & 0.398 & 0.398 & 0.090 & 0.000 & 0.834 & 1.000 & 0.398 & 0.263 & 0.947 & 0.898 & 0.090 & 0.057 & 0.492 & 0.398 & & & \\
\hline 25 & 0.324 & 0.834 & 0.263 & 0.523 & 0.211 & 0.057 & 0.944 & 0.324 & 0.398 & 0.211 & 0.211 & 0.125 & 0.165 & 0.623 & 0.869 & 0.324 & 0.324 & 0.834 & 0.947 & 0.211 & 0.165 & 0.398 & 0.492 & 0.165 & & \\
\hline 26 & 0.165 & 0.995 & 0.125 & 0.419 & 0.165 & 0.165 & 0.673 & 0.263 & 0.324 & 0.165 & 0.263 & 0.263 & 0.125 & 0.492 & 1.000 & 0.398 & 0.263 & 0.623 & 0.492 & 0.090 & 0.125 & 0.492 & 0.398 & 0.125 & 0.165 & \\
\hline
\end{tabular}

Sanur 2,11 - Sanur $1,12=$ Pengulon $2,13=$ Pengulon $1,14=$ Penarukan 2, $15=$ Penarukan $1,16=$ Pemogan $2,17=$ Pemogan $1,18=$ Pemaron $2,19=$ Pemaron $1,20=$ Kalisada 2,10

Kalisada 1,22 = Kalibukbuk 2, 23 = Kalibukbuk 1,24 = Celukan Bawang 2, $25=$ Celukan Bawang 1, 26 = Uma Anyar 2 


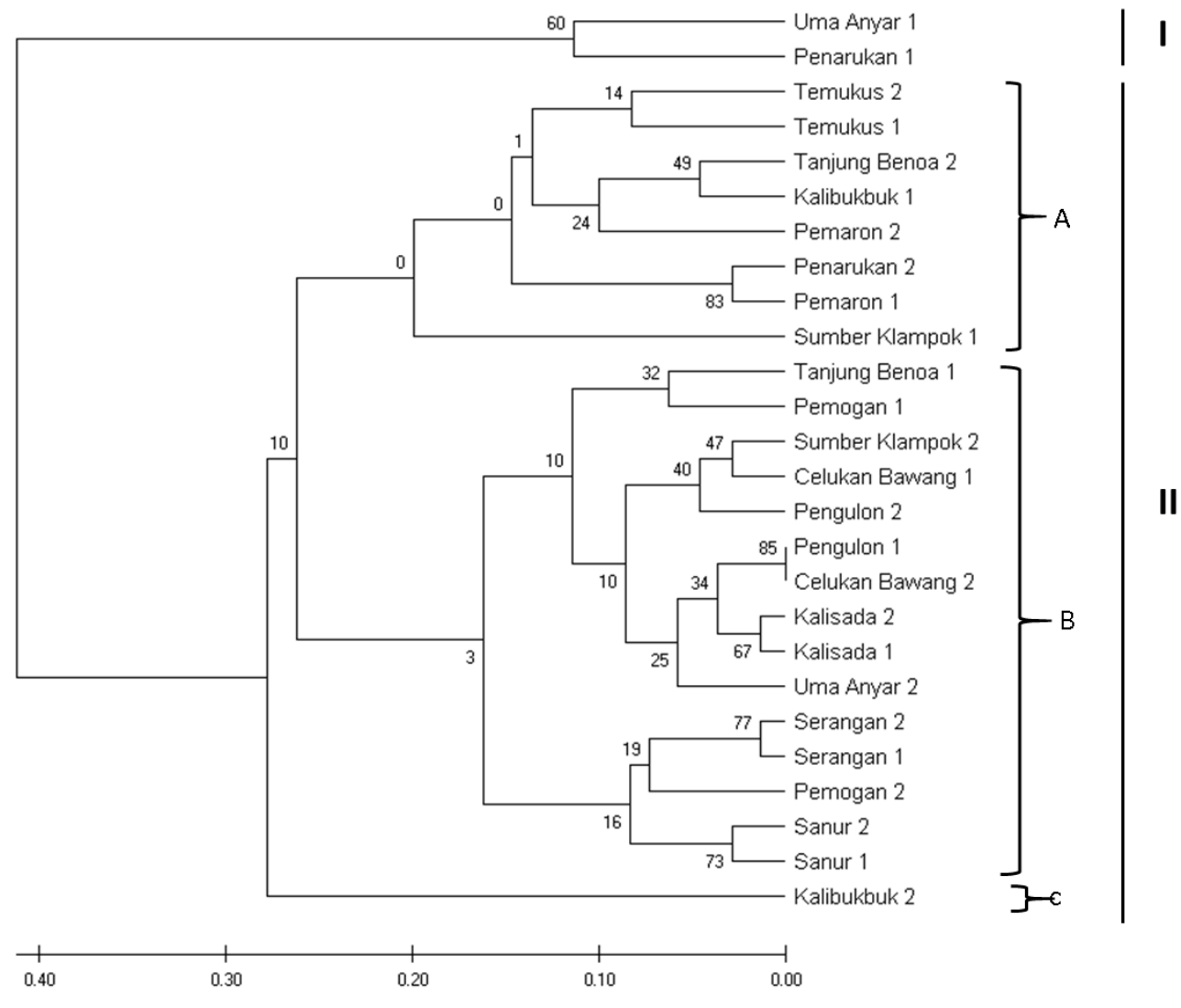

Figure 4. Dendrogram of 26 pongamia trees in Bali based on ISSR analysis using MEGA X software. Scale showed the length of the branch and the numbers on the branch showed bootstrap value

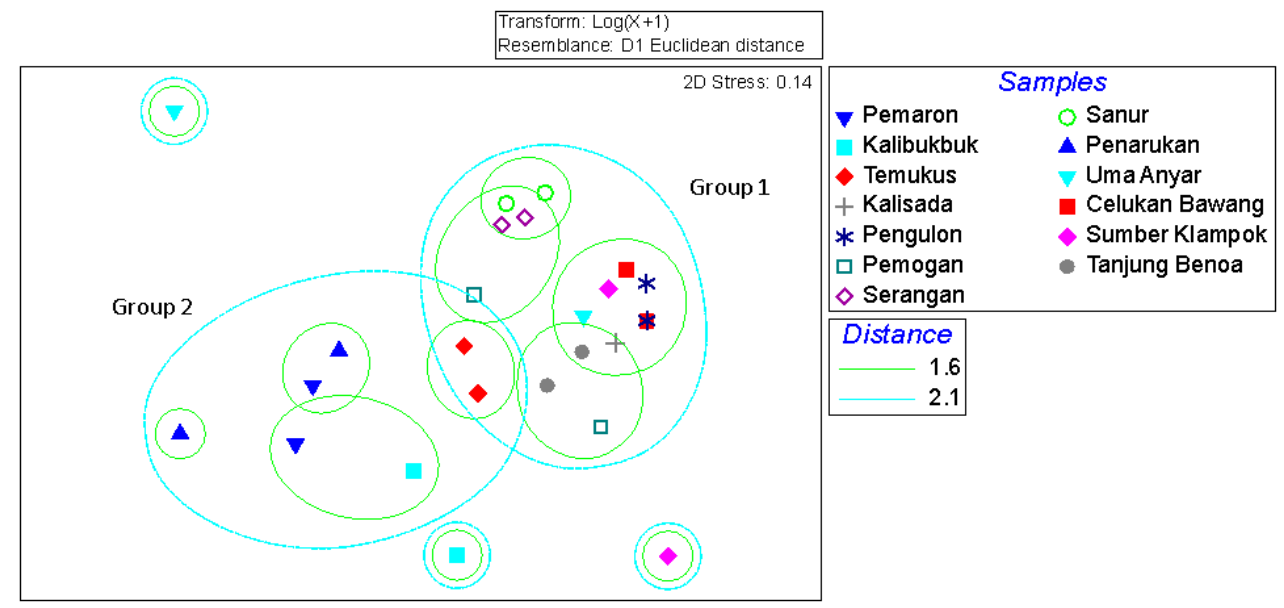

Figure 5. Nonmetric Multidimensional Scaling based on DNA profile using 9 ISSR markers of 26 pongamia samples

Analysis of NMDS using Primer E Version 6 to 26 DNA samples from pongamia indicated that 23 samples were clustered into two main groups with the intersection between the two at Euclidean distance of 2.1 (Figure 5). The first group consisted of pongamia trees from Kalisada, Pengulon, Pemogan, Serangan, Sanur, Uma Anyar, Celukan Bawang, Sumber Klampok, and Tanjung Benoa. The second group consisted of pongamia trees from
Pemaron, Kalibukbuk, and Penarukan. Trees from Temukus and Pemogan were in the intersection of group I and II indicating they shared common parents. There were some trees grouped based on locations with genetic distance 1.6, such as trees from Temukus, Serangan and Sanur Villages. This results confirmed cluster analysis using MEGA X software (Figure 4). 
Figure 4 showed that among 26 pongamia trees studied, only 3 pongamia trees, namely Uma Anyar 1, Penarukan 1, and Kalibukbuk 2 separated from the major group with ranges of genetic distance. Uma Anyar 1 separated with the rest of pongamia trees with genetic distance $0.227-1.324$, Penarukan 1 separated with 0.285-1.000 genetic distance, and Kalibukbuk 2 separated with $0.165-1.194$ genetic distance. Figure 5 showed that only three trees, namely tree from Uma Anyar, Kalibukbuk, and Sumber Klampok separated from the two groups indicating divergence. This existence of low genetic diversity of pongamia in Bali needs to be widened because high genetic diversity is one of the most important issues in breeding program for improvement of the species (Kesari et al. 2010). Previous research in India had found a moderate level of genetic diversity of pongamia using ISSR markers (Sahoo et al. 2010).

In conclusion, based on the analysis of 26 DNA samples of Pongamia pinnata using 9 ISSR markers showed that most pongamia trees in Bali clustered with narrow genetic distance indicating close genetic relationship probably because they came from the same source. Genetic diversity of pongamia in Bali needs to be widened possibly by the introduction of new planting materials from across Indonesia or seed procurement from different sources.

\section{ACKNOWLEDGEMENTS}

We would like to acknowledge Ministry of Research, Technology and Higher Education of Indonesia for funding this research through DIPA PNBP 2018, Udayana University with research scheme Hibah Unggulan Udayana.

\section{REFEENCES}

Aminah A, Supriyanto, Suryani A, Siregar I. 2017. Genetic diversity of Pongamia pinnata (Millettia pinnata, aka. malapari) populations in Java Island, Indonesia. Biodiversitas 18: 677-681.

Arpiwi NL, Yan G, Barbour EL, Plummer JA. 2013a. Genetic diversity, seed traits and salinity tolerance of Millettia pinnata (L.) Panigrahi, a biodiesel tree. Genet Resour Crop Evol 60: 677-692.

Arpiwi NL, Yan G, Barbour EL, Plummer JA, Watkin E. 2013b. Phenotypic and genotypic characterisation of root nodule bacteria nodulating Millettia pinnata (L.) Panigrahi, a biodiesel tree. Plant \& Soil 367: 363-377.

Arpiwi NL, Negara IMS, Simpen IN. 2017. Selection of high oil-yielding trees of Millettia pinnata (L.) Panigrahi, vegetative propagation, and growth in the field. J Trop Life Sci 7: 258-262.

Arpiwi NL, Wahyuni IGAS, Muksin IK, Sutomo. 2018. Conservation and selection of plus trees of Pongamia pinnata in Bali, Indonesia. Biodiversitas 19(5): 1607-1614.

Demeke T, Jenkins GR. 2010. Influence of DNA extraction methods, PCR inhibitors and quantification methods on real-time PCR assay of biotechnology-derived traits. Anal Bioanal Chem 396: 1977-1990.

Grativol C, de Fonseca C, Madeiros L, Hamerly AS, Ferreira PCG. 2011. High efficiency and reliability of Inter-Simple Sequence Repeats (ISSR) markers for evaluation of genetic diversity in Brazilian cultivated Jatropha curcas accessions. Mol Biol Rep 38: 4245-4256.

Kesari V, Krishnamachari A, Rangan L. 2008. Systematic characterization and seed oil analysis in candidate plus tree of biodiesel plant, Pongamia pinnata. Ann Appl Biol 152: 397-404.

Kesari V, Sathyanarayana VM, Parida A, Rangan L. 2010. Molecular marker-based characterization in candidate plus trees of Pongamia pinnata, a potential biodiesel legume. AoB Plants DOI:10.1093/aobpla/plq017.

Kumar M, Mishra GP, Singh R, Kumar J, Naik PK, Singh SB. 2009. Correspondence of ISSR and RAPD markers for comparative analysis of genetic diversity among different apricot genotypes from cold arid desert of Irans-Himalayas. Physiol Mol Biol Plants 15: 225-236.

Loveless MD. 1992. Isozyme variation in tropical trees: patterns of genetic organization. New For 6: 67-94.

Martín MA, Herrera MA, Martín LM. 2012. In situ conservation and landscape genetics in forest species. J Nat Resour Develop 2: 1-5.

Moser BR. 2009. Biodiesel production, properties, and feedstocks. In Vitro Cell Dev Biol Plant 45: 229-266.

Nakanishi H. 1988. Dispersal ecology of the maritime plants in the Ryukyu Islands. Japan Ecol Res 3: 163-173.

Ng WL, Tan SG. 2015. Inter-Simple Sequence Repeat (ISSR) markers: Are we doing it right? ASM Sci J 9: 30-39.

Raju AJS and Rao SP. 2006. Explosive pollen release and pollination as a function of nectar-feeding activity of certain bees in the biodiesel plant, Pongamia pinnata (L.) Pierre (Fabaceae). Curr Sci 90: 960967.

Ramirez AMH, Duque HJS, Trujillo AIU. 2018. Quality of cocoa (Theobroma cacao L.) DNA from foliar tissue at different stages of development. Acta Agron 67: 311-318.

Sahoo DP, Aparijita S, Rout GR. 2010. Inter and intra-population variability of Pongamia pinnata: a bioenergy legume tree. Plant Syst Evol 285: 121-125.

Sharma SS, Negi MS, Sinha P, Kumar K, Tripathi SB. 2011. Assessment of genetic diversity of biodiesel species accessions using AFLP and Three Endonuclease-AFLP. Plant Mol Biol Rep 29: 12-18.

Stagnati L, Soffritti G, Lanubile A, Busconi M. 2017. Comparison of six methods for the recovery of PCR-compatible microbial DNA from an agricultural biogas plant. Appl Microbiol Biotechnol 101: 3907-3917.

Weiss A, Jerome V, Frietag R. 2007. Comparison of strategies for the isolation of PCR-compatible, genomic DNA from municipal biogas plants. J Chromatogr B Analyt Technol Biomed Life Sci 853 (1-2): 190-197 